\title{
The Watt Family, Thomas Beddoes, Davies Giddy, Humphry Davy and the Medical Pneumatic Institution, Bristol
}

\author{
Frank A.J.L. James
}

http://orcid.org/0000-0002-0499-9291

\section{Department of Science and Technology Studies, University College London and the Royal Institution*}

\section{Introduction}

On 7 October 1798 the nineteen-year old Humphry Davy (1778-1829) arrived in Clifton, near Bristol, after a five-day journey from Penzance to take up the role of Superintendent of the new Medical Pneumatic Institution (MPI) being established by Thomas Beddoes (1760-1808). This was the first step in a career that would propel Davy from provincial Cornish obscurity to metropolitan fame, first as Professor of Chemistry at the Royal Institution and later as President of the Royal Society of London.

This story is so well known its very familiarity can obscure the numerous contingencies that permitted Davy to follow this career path. One of these factors involved members of the Watt family

\footnotetext{
* Department of Science and Technology Studies, University College London, Gower Street, London, WC1E 6BT, England; Royal Institution, 21 Albemarle Street, London, W1S 4BS, England; fjames@ri.ac.uk. I thank the following archives for permission to study manuscripts and other documents in their collections: The Royal Institution (RI), the Library of Birmingham (LoB), Cornwall Record Office (CRO), the Royal Institution of Cornwall (RIC), Wedgwood Museum (WM), The National Archives (TNA), the Science Museum (SM), the British Library, Bedfordshire and Luton Archive Service, the Natural History Museum, Carlisle Central Library and the Linnean Society. Letters written by Humphry Davy will be published in Tim Fulford and Sharon Ruston, eds., Jan Golinski, Frank A.J.L. James and David Knight, advisory eds., The Collected Letters of Sir Humphry Davy (4 volumes, Oxford: Oxford University Press, 2019). In the meantime, this essay cites their archival or printed locations. The letters of Robert Southey are freely available at www.rc.umd.edu/editions/southey_letters and are cited only by writer (Southey), recipient and date. Because of the tendency of the Watt and Wedgwood families to use the same forenames in succeeding generations, both the fore- and surnames of correspondents are given consistently in the notes. Note on currency: $f 1$ was divided into 20 shillings (s) and in turn a shilling was composed of 12 pennies (d). A guinea was $21 \mathrm{~s}$ or $f 11 \mathrm{~s}$.
} 
in various direct and indirect ways in supporting and promoting Davy's career. James Watt sr (17361819) and his sons James Watt jr (1769-1848) and Gregory Watt (1777-1804) all contributed indirectly to Davy's rise by their backing and funding the MPI, while Gregory provided support directly by recommending Davy to Beddoes. This essay will trace in some detail how these links originated and developed. When examined at the level of detail I deploy here, the need for various meta-narratives, such as the Enlightenment, Romanticism or the role of the Lunar Society disappear. They have been invoked to help provide what some historians think is a necessary theoretical framework linking scientific knowledge and method with engineering practice and industrialisation. Such meta-narratives add an extra, and I suggest in this case, unnecessary, analytical layer to account for general events such as eighteenth-century industrialisation ${ }^{1}$ or specific occurrences such as founding the MPI or Davy's career trajectory including the role of the Watt family of engineers. ${ }^{2}$

\section{The Medical Pneumatic Institution}

The MPI's aim was to investigate whether or not the factitious airs or gases identified during the previous half century or so by, among others, Joseph Black (1728-1799), Joseph Priestley (17331804) and Henry Cavendish (1731-1810), possessed any therapeutic properties, especially in the cure or mitigation of consumption. The MPI had been established following a protracted public fundraising campaign during the previous four years organised by Beddoes. ${ }^{3} \mathrm{~A}$ politically and medically radical Oxford, London and Edinburgh trained physician, he received in 1786 his MD from

\footnotetext{
${ }^{1}$ Joel Mokyr, The Gifts of Athena: Historical Origins of the Knowledge Economy (Princeton: Princeton University Press, 2002) and Margaret C. Jacob, Scientific Culture and the Making of the Industrial West (Oxford: Oxford University Press, 1997) both claim that the 'scientific revolution' and 'the enlightenment' were essential for industrialisation in eighteenth-century Britain. This view has been criticised in Peter M. Jones, Industrial Enlightenment: Science, technology and culture in Birmingham and the West Midlands, 1760-1820 (Manchester: Manchester University Press, 2008), especially pp.13-21. This essay extends Jones's critique by querying the need, in this instance at least, for any general explanatory framework.

2 Examples would include Roy Porter, Doctor of Society: Thomas Beddoes and the Sick Trade in LateEnlightenment England (London: Routledge, 1992); Ferdinando Abbri, 'Romanticism versus Enlightenment: Sir Humphry Davy's idea of chemical philosophy' in Stefano Poggi and Maurizio Bossi, eds., Romanticism in science: Science in Europe, 1790-1840 (Dordrecht: Kluwer, 1994), pp.31-47; Trevor H. Levere, 'Between Enlightenment and Romanticism: The Case of Dr Thomas Beddoes' in Robert M. Brain, Robert S. Cohen and Ole Knudsen, eds., Hans Christian Ørsted and the Romantic Legacy in Science (Dordrecht: Springer, 2007), pp.25972.

${ }^{3}$ Detailed in Frank A.J.L. James, "the first example ... of an extensive scheme of pure scientific medical investigation': Thomas Beddoes and the Medical Pneumatic Institution in Bristol, 1794 to 1799', Royal Society of Chemistry Historical Group Occasional Papers, 2016, No. 8.
} 
Oxford University. ${ }^{4}$ The following year he became Reader in Chemistry there, a position he held until 1792 during which period he first suggested the idea of using gases for therapeutic purposes. ${ }^{5} \mathrm{His}$ enforced resignation as Reader came about because of his anti-government, pro French revolution, pro Jacobin and general democratic politics, not then a British value. Indeed, subjected to Home Office surveillance and harassment, Beddoes appeared on a list of 'Disaffected \& Seditious Persons' along with Priestley and others; ${ }^{6}$ he is thus one of Kenneth Johnston's Unusual Suspects. ${ }^{7}$ By the time of Davy's arrival in Clifton Beddoes had obtained just over $£ 2000$ for the MPI, well short of the target of between three and five thousand pounds he had set himself in 1794. The failure to reach the required amount was ascribed at the time to Beddoes's politics, for example by Watt sr's second wife, Anne Watt (c.1744-1832). ${ }^{8}$

What is quite remarkable is that Beddoes put Davy in charge of spending this money despite having never previously met him. This suggests Beddoes placed a high degree of confidence in those who recommended Davy to him as a suitable person to be Superintendent. These backers included, James and Anne Watt's son Gregory Watt as well as Thomas Wedgwood (1771-1805), son of the Midlands potter Josiah Wedgwood (1730-1795), and Davies Giddy (1767-1839), a minor member of the Cornish gentry and former student of Beddoes's. That Davy had come to know well all these people and gain their full confidence and support illustrates how just obtaining the chance to pursue scientific interests in late eighteenth-century England was subject to the vagaries of major contingencies.

\section{Humphry Davy}

Davy, born in Penzance on 17 December 1778, was the first child of Robert Davy (1746-1794) and Grace Millet (1752-1826). ${ }^{9}$ Her parents, who had lived with the Penzance surgeon John Tonkin

\footnotetext{
${ }^{4}$ On Beddoes see Trevor H. Levere, Larry Stewart, Hugh Torrens and Joseph Wachelder, The Enlightenment of Thomas Beddoes: Science, medicine, and reform (London: Routledge, 2017) and Dorothy Stansfield, Thomas Beddoes M.D., 1760-1808: Chemist, Physician, Democrat (Dordrecht: Reidel, 1984).

${ }^{5}$ Recollected in Thomas Beddoes to Davies Giddy, 2 March 1795, CRO DG/42/35.

6 'Disaffected \& seditious persons', 28 July 1792, TNA HO42/21, f.214-5. See also Evan Nepean to Isaac Browne, 1 November 1792, TNA HO42/22, f.233-4 (copy).

${ }^{7}$ Kenneth R. Johnston, Unusual Suspects: Pitt's Reign of Alarm and the Lost Generation of the 1790s (Oxford: Oxford University Press, 2013) devoted a chapter (pp.96-110) to Beddoes.

${ }^{8}$ Anne Watt to Gregory Watt, 30 March 1795, LoB MS 3219/7/1/22.

${ }^{9}$ On Davy see Harold Hartley, Humphry Davy (London: Nelson, 1966); David Knight, Humphry Davy: Science and Power (Oxford: Blackwell / Cambridge: Cambridge University Press, 1992/1996); June Z. Fullmer, Young Humphry Davy: The Making of an Experimental Chemist (Philadelphia: American Philosophical Society, 2000);
} 
(c.1719-1801), both died within a few days of each other in May 1757, whereupon Tonkin took a strong interest in their children and later grandchildren. ${ }^{10}$ In September 1776 at the age of twentyfive Grace Millet married Robert Davy, five or six years her senior. He owned the copyhold of a small estate at Varfell (two miles or so east of Penzance) that he farmed. ${ }^{11}$ Davy's childhood was divided between Varfell where his father built a house in $1782^{12}$ and Tonkin's house in Penzance. ${ }^{13}$ Quickly apparent that Davy was very bright indeed, to which numerous anecdotes testify, ${ }^{14}$ he attended a prep and grammar school in Penzance. In 1793, just after his fourteenth birthday, he went for a year, at Tonkin's expense, ${ }^{15}$ to the grammar school in Truro, about twenty-five miles north east of Penzance, presumably with the intention to go either to the universities of Oxford or Cambridge or possibly Edinburgh to study medicine.

The reason why Tonkin bore the cost of Davy's education was probably due to the financial difficulties of the latter's father. Despite opposition from his wife, he had invested in a mine near Varfell which, from the parlour window of the house, he would show his youngest son, John Davy (1790-1868), telling him his fortune lay there. ${ }^{16}$ Also Robert Davy's health was declining and he died on 10 December $1794,{ }^{17}$ just a week before Davy's sixteenth birthday, leaving his widow with about $£ 1300$ of debt from his mining ventures, ${ }^{18}$ an annual income of $£ 150^{19}$ and five children: Humphry, John and three sisters of intermediate ages between their brothers (Katherine Davy (1781-1860),

Jan Golinski, The Experimental Self: Humphry Davy and the Making of a Man of Science (Chicago: University of Chicago Press, 2016).

${ }^{10} \mathrm{RI}$ MS HD/26/D/79, f.2v. This is one of five short recollections of Davy's early life written by his sister Katherine Davy in the late 1820s and early 1830s. They are RI MS HD/26/D/71 (undated), 75 (4 January 1831, watermark 1828), 79 (watermark 1828), 80 (watermark 1825) and 81 (watermark 1825). The author is identified in $/ 75$, p.1. Katherine Davy wrote them to provide information for Davy's early biographies. See Frank A.J.L. James, 'Constructing Humphry Davy's Biographical Image', Ambix, forthcoming 2019.

11 John Davy, Memoirs of the Life of Sir Humphry Davy, Bart. (2 volumes, London: Longman, 1836), 1: 6. Fullmer, Young Humphry Davy, p.11.

${ }^{12}$ Katherine Davy, recollection, RI MS HD/26/D/80, p.2.

${ }^{13}$ John Paris, The Life of Sir Humphry Davy, Bart. (2 volumes, London: Colburn and Bentley, 1831), 1: 5.

${ }^{14}$ Paris, Life of Sir Humphry Davy, 1: 4-10; Davy, Memoirs of the Life of Sir Humphry Davy, 1: 12-13.

${ }^{15}$ Davy, Memoirs of the Life of Sir Humphry Davy, 1: 19-20. Tonkin notes on his interactions with the Davy family records paying for Davy's education are in RI MS HD/26/D/66, f.18r. These notes were published in Gillian Green, 'The Boyhood of Humphry Davy in Penzance' in June Palmer, ed., In and around Penzance during Napoleonic Times (Penzance: Penwith Local History Group, 2000), pp.70-7 on pp.72-5.

${ }^{16}$ Katherine Davy, recollection, RI MS HD/26/D/80, p.3.

${ }^{17}$ Notes copied from the Davy family Bible, in Katherine Davy's hand, RI MS HD/26/D/74.

${ }^{18}$ Katherine Davy, recollection, RI MS HD/26/D/80, p.1.

${ }^{19}$ Davy, Memoirs of the Life of Sir Humphry Davy, 1: 7. 
Grace Davy (b.1786) and Elizabeth Davy (1788-1830)). It is little wonder, therefore, that Davy's mother moved to Penzance and within two months, on 10 February 1795, apprenticed him for five years to the surgeon and apothecary John Borlase (1753-1813) for a $f 60$ premium, paid for, once again, by Tonkin. ${ }^{20}$ Grace Davy formed a business partnership with a French refugee and they opened a milliners shop in Penzance. Together with taking in lodgers, this business kept her financially secure until 1799 when she inherited a small estate that doubled her income, thus allowing her to dissolve the partnership. ${ }^{21}$

\section{Gregory Watt}

One of those who lodged with Grace Davy towards the end of 1797 was Gregory Watt. He had pursued a brilliant career as a student at Glasgow University between 1792 and 1796 winning prizes in mathematics, Greek translation and theology. ${ }^{22} \mathrm{He}$ then joined the Birmingham-based engineering business run by his father in partnership with Matthew Boulton (1728-1809).

In 1793 Gregory's only full sibling, his sister Jessy Watt (1779-1794), a couple of years younger than him, began suffering from consumption. The radical physician Erasmus Darwin (17311802) prescribed for her via letters written from Derby ${ }^{23}$ and at the end of May 1794, Beddoes came to Birmingham for a week to treat her with various gases - news of his therapeutic ideas had evidently circulated. He and Watt sr constructed some apparatus for her to inhale the gases, but to no avail and she died on 6 June aged fifteen. ${ }^{24}$ The following month Watt sr wrote up the details of the construction of the apparatus in the form of a letter to Beddoes dated 14 July 1794. This Beddoes published as the second part of his and Watt's Considerations on the Medicinal Use of Factitious Airs and on the Manner of Obtaining them in Large Quantities. ${ }^{25}$ The first edition,

\footnotetext{
${ }^{20}$ Both parts of Davy's apprentice indenture survive in RI MS HD/5/3 and RIC MS DVY/1. For the premium see Tonkin's notes, RI MS HD/26/D/66, f.19v.

${ }^{21}$ Davy, Memoirs of the Life of Sir Humphry Davy, 1: 8.

22 William Innes Addison, Prize Lists of the University of Glasgow: From Session 1777-78 to Session 1832-33 (Glasgow: Carter and Pratt, 1902), pp.56, 58, 60, 64-5, 67-9.

${ }^{23}$ Erasmus Darwin to James Watt sr, 13 December 1793, 1 January 1794, Erasmus Darwin to Anne Watt, 12 March 1794, Erasmus Darwin to James Watt sr, 25 April 1794, 25 May 1794, 29 May 1794, 6 June 1794 in Desmond King-Hele, ed., The Collected Letters of Erasmus Darwin (Cambridge: Cambridge University Press, 2007), pp.424-5, 426-7, 431-2, 433-5, 436-7, 437-8 and 439.

24 James Watt sr to Joseph Black, 9 June 1794, Robert G.W. Anderson and Jean Jones, eds., The Correspondence of Joseph Black (2 volumes, Farnham: Ashgate, 2012), 2: letter 731.

${ }^{25}$ James Watt sr, 'Description of an Air Apparatus; with Hints Respecting the Use and Properties Of Different Elastic Fluids' in Thomas Beddoes and James Watt, Considerations on the Medicinal Use of Factitious Airs, and
} 
published mid-October, was followed by a second that appeared in mid-1795. On the title page of the first edition, Beddoes used his post-nominal MD whilst Watt was given as esquire, but in the second it changed to 'Engineer', doubtless reflecting his concerns with the social and professional standing of engineers at least compared to physicians. Watt's apparatus formed the basis of the equipment Beddoes would use thereafter for administering gases. ${ }^{26}$ Thereafter Watt retained a strong interest in pneumatic medicine for the remainder of his life ${ }^{27}$ including manufacturing and selling the apparatus. ${ }^{28}$ This provides additional evidence for David Miller's view that Watt should not be viewed solely as an engineer. ${ }^{29} \mathrm{His}$ many letters to Beddoes discuss pneumatic medicine at length and it seems to me the suggestion that Beddoes took advantage of Watt's grief for his own purposes is wide of the mark. ${ }^{30}$ Watt's sr relations with Beddoes were no different than with, for instance, the Wedgwood family in displaying deep knowledge of and strong interest in areas outside steam engineering. Furthermore, Watt sr's interest became more intense when in 1797 Gregory began displaying early symptoms of consumption.

In such cases, the usual practice for the wealthy to mitigate, if not cure, the disease, was to go aboard, preferably to Italy. However, following the guillotining of Louis XVI (1754-1793) on 21 January 1793 Britain found itself at war against Revolutionary France, making continental travel, while just about possible, a difficult and sometimes dangerous option. Penzance came to be seen as an attractive alternative due to its perceived mild climate. For example, Josiah Wedgwood jr (17691843), his brother Tom, also ill, and a couple of their sisters were there in autumn $1797 ;{ }^{31}$ Tom left in

on the manner of obtaining them in large quantities (London: Johnson and Murray, [1794]), part 2. Whether the date that Watt sr, who abhorred both democracy and tyranny (see James Watt sr to Joseph Black, 17 July 1793, Black, Correspondence 2: letter 703), chose for this letter was deliberate remains an open question.

${ }^{26}$ The best account of the collaboration between Watt and Beddoes and how it has been treated historically is David Philip Miller and Trevor H. Levere, “'Inhale it and See?"' The Collaboration between Thomas Beddoes and James Watt in Pneumatic Medicine', Ambix, 2008, 55: 5-28.

${ }^{27}$ David Philip Miller, James Watt, Chemist: Understanding the Origins of the Steam Age (London: Pickering and Chatto, 2009), p.114. Miller and Levere, "'Inhale it and See?", p.8.

${ }^{28}$ For instance, see James Watt sr to Joseph Black, 1 June 1796, Black, Correspondence 2: letter 762; Thomas Beddoes to Davies Giddy, 29 June 1796, CRO DG/42/20; Patrick Copland to James Watt sr, 3 January 1804, LoB MS 3219/4/46/6.

${ }^{29}$ Miller, James Watt, Chemist.

${ }^{30}$ Richard L. Hills, James Watt. Volume 3: Triumph through Adversity, 1785-1819 (Ashbourne: Landmark Publishing, 2005), p.153.

${ }^{31}$ Thomas Wedgwood and Josiah Wedgwood jr to James Watt jr, 15 October 1797, LoB MS 3219/6/2/W/201. 
February $1798^{32}$ and the others the following month. ${ }^{33}$ However, the former unimpressed, commented in a letter to Watt jr that Penzance's winds and rains made it 'by no means a paradise'. ${ }^{34}$ Nevertheless, the Birmingham physician William Withering (1741-1799), supported by Beddoes, recommended Cornwall for Gregory Watt. ${ }^{35}$ Beddoes thought it was a better idea than going to Germany, ${ }^{36}$ though he thought it would not benefit Watt sr's other son, from his first marriage, James Watt jr. ${ }^{37}$ Thus with some sense of resignation Watt sr, in October 1797, told Watt jr 'we must content ourselves with Cornwall', though he did not want Gregory to 'whol[I]y lose his time' whilst in Cornwall, but continue to learn the business whilst recuperating. ${ }^{38}$ The following month he instructed Gregory to 'fix your quarters in Penzance' and also that he should go to Clifton and 'Take Dr. Beddoes directions in regard to the preservation of your own health'. ${ }^{39}$ This advice consisted, apparently, of 'eating animal food at breakfast' and 'avoid[ing] the direct \& indirect causes of debility'. ${ }^{40}$ Watt sr also cautioned his younger son about the people he would meet in the county, naming some who were acceptable, adding 'sincerity is not a Cornish virtue'41 - a reference to his experiences in dealing with those Cornish engineers (pirates as he called them) who had, in his view, infringed his steam engine patent.

In the end Gregory left Birmingham around 22 November, arriving in Truro on the last day of the month. ${ }^{42} \mathrm{~A}$ few days later he travelled to Penzance where he met the Wedgwoods and told his father that he had

Examined the whole town in search of Lodgings which are neither plentiful nor cheap. - At length however I found a very decent parlour and bedroom in the house

\footnotetext{
32 Thomas Wedgwood to James Watt jr, 23 February 1798, LoB MS 3219/6/2/W/202.

${ }^{33}$ Gregory Watt to James Watt sr, 8 March 1798 and 22 March 1798, LoB MS 3219/7/49/11 and 12.

34 Josiah Wedgwood jr to James Watt jr, 29 October 1797, LoB MS 3219/6/2/W/182.

35 James Watt sr to Joseph Black, 7 February 1798, Black, Correspondence 2: letter 789.

${ }^{36}$ Thomas Beddoes to James Watt sr, 24 October 1797, LoB MS 3219/4/29/23.

37 James Watt jr to James Watt sr, 3 November 1797, LoB MS 3219/4/14/33.

38 James Watt sr to James Watt jr, 20 October 1797, LoB MS 3219/6/1/126. Published in Jennifer Tann, The Selected Papers of Boulton and Watt: Volume 1 The Engine Partnership, 1775-1825 (Cambridge, MA: MIT Press, 1981), pp.239-40.

39 James Watt sr to Gregory Watt, 15 November 1797, LoB MS 3219/4/118/48

40 Thomas Beddoes to James Watt sr, 24 October 1797, LoB MS 3219/4/29/23.

${ }^{41}$ James Watt sr to Gregory Watt, 15 November 1797, LoB MS 3219/4/118/48.

${ }^{42}$ Gregory Watt to James Watt sr, 2 December 1797, LoB MS 3219/7/49/2.
} 
of an old or rather elderly lady who bears an exceedingly good character. She provides every thing except tea coal \& candle for a guinea a week $-^{43}$

Grace Davy was then aged around forty-five, suggesting either for Gregory, just turned twenty, anyone over the age of forty was old, or she had been prematurely aged by the strain of being a single mother supporting five children and running a small business. And to his half-brother Gregory wrote he had found 'comfortable quarters ... which I propose to take possession [of] in a short time'. ${ }^{44}$ Gregory briefly spent some time in Truro before, just under a fortnight, later returning to Penzance on 19 December where he lodged with the Davys until March when he moved to Redruth, a mining town nearly twenty miles to the north east. ${ }^{45}$

On the evening of his arrival in Penzance, Gregory Watt met Giddy at the Wedgwoods. ${ }^{46}$ Giddy with Beddoes (whose student he had been) in 1791 had geologised on the Lizard wearing French revolutionary cockades in their hats. ${ }^{47}$ At that time the government sought to suppress English Jacobins either by straightforward repression or by drawing them into the governing class. They succeeded with Giddy who the following year was appointed, aged twenty-five, High Sheriff of Cornwall, ${ }^{48}$ a position which as a member of the gentry, especially minor, was one he could not possibly have refused. Beddoes, made of sterner stuff, did not succumb to the temptation dangled before him by the government of a Regius chair of chemistry at Oxford, an episode documented by Trevor Levere ${ }^{49}$ which contributed to his departure from the 'temple of the muses'.$^{50}$

We do not know how much Gregory knew of Giddy's background when he met him at the Wedgwoods. He told his father the conversation turned immediately to Boulton and Watt's legal action against those who they argued had infringed his patent. ${ }^{51} \mathrm{His}$ father, replying by return,

\footnotetext{
${ }^{43}$ Gregory Watt to James Watt sr, c.15 December 1797, LoB MS 3219/7/49/3.

${ }^{44}$ Gregory Watt to James Watt jr, 6 December 1797, LoB MS 3219/6/1/137.

${ }^{45}$ Gregory Watt to James Watt jr, 1 April 1798, LoB MS 3147/3/76/6.

${ }^{46}$ Gregory Watt to James Watt sr, 20 December 1797, LoB MS 3219/7/49/4.

${ }^{47}$ Stansfield, Thomas Beddoes, p.44. See also A.C. Todd, Beyond the Blaze: A Biography of Davies Gilbert (Truro: D. Bradford Barton, 1967), p.34.

48 Todd, Beyond the Blaze, p.34.

${ }^{49}$ Trevor H. Levere, 'Dr. Thomas Beddoes at Oxford: Radical Politics in 1788-1793 and the fate of the Regius Chair in Chemistry', Ambix, 1981, 28: 61-9. For an alternative view see A.V. Simcock, The Ashmolean Museum and Oxford Science, 1683-1983 (Oxford: Museum of the History of Science, 1984), pp.35-6.

50 Thomas Beddoes to Davies Giddy, 7 April 1793, CRO MS DG/41/2.

${ }^{51}$ Gregory Watt to James Watt sr, 20 December 1797, LoB MS 3219/7/49/4.
} 
advised Gregory to cultivate Giddy, but exercise caution. ${ }^{52}$ This was wise counsel as Giddy quickly convinced Gregory that he had nothing to do with Jonathan Hornblower (1753-1815) or the steam engines Hornblower had erected in Cornwall, much to the annoyance of Boulton and Watt. ${ }^{53}$ However, precisely contemporary letters from Giddy to Hornblower as well as Giddy's diary, demonstrate both the existence of a strong connection with Hornblower and that the account he gave Gregory Watt was not entirely straightforward. ${ }^{54}$

According to Katherine Davy's much later recollection, Gregory, almost exactly a year older than Davy, became one of the family, ${ }^{55}$ but there are no references to Davy in Gregory's letters to Birmingham written during this period. Indeed, Watt sr seems not to have known Gregory's address in Penzance as his letters went to Truro and then forwarded. Such omissions suggest the existence of significant class differences between Davy and Gregory. Certainly, Gregory described to his father his interactions with various members of the Cornish gentry, including Giddy, but not with Davy who, as an apothecary's apprentice, was simply not involved with Gregory's life beyond their personal contact. These included, again according to Katherine, Gregory and Davy rambling about the countryside collecting minerals on which Watt wrote a twelve page sketch for William Withering jr (1776-1832) - making no reference whatsoever to Davy. ${ }^{56}$ They also visited mines, as Watt had been enjoined to do by his father, including Wheal Wherry where he doubtless wished to investigate Hornblower's steam engine there. ${ }^{57}$ By visiting many West Cornish mines with such a guide as Gregory, Davy became familiar with one of the key engineering elements of industrialisation. Watt jr later recollected that Gregory 'was pleased with his [Davy's] talents and disposition and took pains to direct his studies ... and spoke of him among his friends as an extraordinary young man' ${ }^{58}$

\section{Davy and Chemistry}

\footnotetext{
52 James Watt sr to Gregory Watt, 24 December 1797, LoB MS 3219/7/1/34

${ }^{53}$ Gregory Watt to James Watt sr, 28 December 1797, LoB MS 3219/7/49/5. See Hills, James Watt, pp.175-83 and Todd, Beyond the Blaze, pp.57-78.

${ }^{54}$ Davies Giddy to Jonathan Hornblower, 20 January 1798 and 2 February 1798, RIC MS Hornblower, ff. 71 and 72. Davies Giddy, Diary, 26 January 1798, CRO DG 16.

55 Katherine Davy, recollection, 4 January 1831, RI MS HD/26/D/75, p.1

${ }^{56}$ Gregory Watt, 'Sketch of the Mineralogy of the County of Cornwall', October 1798, LoB MS 3219/7/28/1214.

${ }^{57}$ Davy, Memoirs of the Life of Sir Humphry Davy, 1: 44-6.

58 James Watt jr to John Craig, 24 September 1831, RI MS HD/26/D/67.
} 
By the end of 1797 Davy had been apprenticed to Borlase for nearly three years, but it seems it was only around the time Gregory Watt and Tom Wedgwood came to Penzance that he began studying chemistry seriously. Davy later recollected beginning his chemical studies in March $1798,{ }^{59}$ which is supported both by his sister's account ${ }^{60}$ and by the absence of chemistry in his earliest surviving notebooks. ${ }^{61}$ He read (in French, which he had learned from an émigré ${ }^{62}$ ) the Traité élémentaire de Chimie by Antoine Lavoisier (1743-1794) and A Dictionary of Chemistry by William Nicholson (17531815), ${ }^{63}$ while Watt read Elements of Mineralogy by Richard Kirwan (1733-1812). ${ }^{64}$

Furthermore, Davy also undertook some chemical experiments ${ }^{65}$ and it seems it was these which contributed to drawing him to Giddy's notice rather than his acquaintance with Gregory Watt or the Wedgwood brothers. As Giddy told Thomasina Dennis (1770-1800), an aspiring writer to whom he taught Greek and Latin,

I was first introduced to his acquaintance by Mr. John Dennis and never felt myself more surprised on discovering a young man situated in all respects so disadvantageously as Mr. Davy prosecuting experiments and investigations worthy of Doctor Priestl[e]y. I could not but be the more astonished, perfectly remembering his late father ${ }^{66}$

I assume that was not a compliment to Robert Davy. Giddy's account agrees well with Katherine Davy's recollection that Davy showed 'Mr John' (by 1835 'one of the oldest inhabitants of

\footnotetext{
59 Humphry Davy, Researches, Chemical and Philosophical; Chiefly Concerning Nitrous Oxide, or Dephlogisticated Nitrous Air, and its Respiration (London: Johnson, 1800), p.453.

${ }^{60}$ Katherine Davy, recollection, 4 January 1831, RI MS HD/26/D/75, p.1.

${ }^{61}$ Both of these are from the mid-1790s. RI MS HD/13/F dealt mostly with general philosophical topics while RI MS HD/21/A principally contains mathematical exercises.

62 Paris, Life of Sir Humphry Davy, 1: 16.

63 Davy, Memoirs of the Life of Sir Humphry Davy, 1: 42. Antoine Lavoisier, Traité élémentaire de Chimie (2 vols., Paris: Cuchet, 1789; 2nd ed., 2 vols., 1793). William Nicholson, A Dictionary of Chemistry (2 vols., London: Robinson, 1795). Humphry Davy, 'An Essay on Heat and the Combinations of Light', June 1798, RIC MS DVY/2, p.3 quoted Lavoisier, Traité, 1: 6 (same page in both editions).

${ }^{64}$ Gregory Watt to James Watt sr, 19 January 1798, LoB MS 3147/3/76/3. Richard Kirwan, Elements of Mineralogy (London: Elmsly, 1784; 2nd ed., 2 vols., 1794-6).

65 Davy, Memoirs of the Life of Sir Humphry Davy, 1: 43-4.

${ }^{66}$ Davies Giddy to Thomasina Dennis, 17 November 1798, CRO DG/87/1/20.
} 
Penzance ${ }^{67}$ ) some experiments he had been doing in a room in Tonkin's house. Dennis did not understand them, but offered to introduce Davy to Giddy. ${ }^{68}$

Although we don't know when this introduction was made, it proved decisive for Davy since Giddy actively supported talented Cornish people, Hornblower being a good example. For instance as a result of his meetings with the Wedgwoods, when they were in Penzance, Giddy secured for Thomasina Dennis a position with them as a governess, though that did not prove especially successful. ${ }^{69}$ Thus Giddy's patronage of Davy was well in line with his normal practice and he gave him access to his library at his house Tredea, a few miles north east of Penzance; doubtless he also lent him books as he had to Gregory Watt. ${ }^{70} \mathrm{He}$ also introduced Davy to John Edwards (1731-1807), the manager of the Cornish Copper Company at Hayle, on the coast to the north east of Penzance. The Company's works possessed a well-equipped laboratory where Davy expressed 'tumultuous delight on seeing, for the first time, a quantity of chemical apparatus, hitherto only known to him through the medium of engravings' ${ }^{71}$ Davy would have doubtless become aware of the use of chemical knowledge and methods in industry.

The resources Davy accessed enable him to conduct numerous experiments including using an air pump to contradict Lavoisier's theory that light was a modification of caloric, a material, though imponderable, substance he had proposed to account for the phenomena of heat. Davy did this by firing a flintlock in a vacuum and showing that light was not produced. ${ }^{72} \mathrm{He}$ also argued against the existence of caloric itself, by demonstrating that when two pieces of ice rubbed against each other, the friction alone melted them - experiments he performed both without and within an air pump. ${ }^{73}$ (Davy's experimental skills so impressed Giddy he recalled them at some length in his Royal Society of London anniversary address following Davy's death. ${ }^{74}$ ) From these and other experiments Davy concluded, contra Lavoisier, that heat was immaterial. Instead, in effect, he

\footnotetext{
${ }^{67}$ Davy, Memoirs of the Life of Sir Humphry Davy, 1: 48.

${ }^{68}$ Katherine Davy, recollection, RI MS HD/26/D/79, p.3r-v.

${ }^{69}$ R.S. Woof, 'Coleridge and Thomasina Dennis', University of Toronto Quarterly, 1962, 32: 37-54.

70 Davies Giddy to Gregory Watt, 20 January 1798, LoB MS 3219/7/5/53.

${ }^{71}$ Paris, Life of Sir Humphry Davy, 1: 47.

72 Humphry Davy, 'An Essay on Heat and the Combinations of Light', June 1798, RIC MS DVY/2, p.3.

73 Humphry Davy, 'An Essay on Heat and the Combinations of Light', June 1798, RIC MS DVY/2, p.6-7. Night temperatures for most of March 1798 fell below freezing point in London. 'Meteorological Journal', Philosophical Transactions, 1799, 89: 6-7.

74 The text of this address, delivered on 30 November 1829, is in Philosophical Magazine, 1830, 3: 33-46; for the recollection see p.38.
} 
substituted light to perform the function that heat did in Lavoisier's system; hence according to Davy oxygen was in combination with light and hence should be called phosoxygen.

A little while before Benjamin Thompson, Count Rumford (1753-1814), had also concluded, by different experiments, that heat was immaterial. He published his results in a paper read to the Royal Society of London on 25 January $1798 .{ }^{75}$ He sent Beddoes a copy who told Giddy about it in mid-April 1798, adding he had for 'some time given up caloric \& I have thought that the phaenomena are well reducible to vibration' ${ }^{76}$ According to Beddoes that month Davy sent him a letter 'containing an account of his researches on heat and light', 77 an action which might have been prompted by Giddy. On the other hand Beddoes said his reply provided Davy with his first knowledge of Rumford's work, suggesting Beddoes thought Giddy had not told Davy about Rumford. ${ }^{78}$ By June Davy had drafted a long paper on his experiments and theories, including an overly flattering reference to Beddoes's success in applying chemistry to medicine who thus 'deserve[d] the eternal approbation of Mankind', as well as mentioning Rumford's work. ${ }^{79}$ Gregory Watt may have taken this manuscript to Bristol on his way back to Birmingham in the second half of June. ${ }^{80}$ In mid-July Beddoes told Watt sr that after reading Davy's 'acc'. of some exps. of his ... he appears to me to have uncommon talents of philosophical investigations' ${ }^{81}$

\section{Funding the Medical Pneumatic Institution}

At precisely this time Beddoes was searching for a suitable person to appoint to be the MPI's Superintendent. For nearly four years from autumn 1794 until mid-1798, he had worked with his major supporters, including Georgiana Cavendish, Duchess of Devonshire (1757-1806), Darwin,

\footnotetext{
${ }^{75}$ Rumford, 'An Inquiry concerning the Source of the Heat which is excited by Friction', Philosophical Transactions, 1798, 88: 80-102.

${ }^{76}$ Thomas Beddoes to Davies Giddy, 14 April 1798, CRO DG/42/2.

77 Thomas Beddoes, 'Specimen of an Arrangement of Bodies according to their Principles' in Thomas Beddoes, ed., Contributions to physical and medical knowledge, principally from the West of England (London: Longman, 1799), pp.207-230, p.212.

${ }^{78}$ Beddoes, 'Specimen', p.212.

${ }^{79}$ Humphry Davy, 'An Essay on Heat and the Combinations of Light', June 1798, RIC MS DVY/2, pp.62 and 48 respectively.

${ }^{80}$ Gregory Watt to Boulton \& Watt, 12 June 1798, LoB MS 3147/3/76/11 noted that he was about to leave Truro. He had dined with Giddy in Tredea at the end of May (Giddy, Diary, 31 May 1788, CRO DG/16) which would have allowed him to take the manuscript from Davy. Also, Paris, Life of Sir Humphry Davy, 1: 52 reports that Gregory Watt did this.

${ }^{81}$ Thomas Beddoes to James Watt sr, 15 July 1798, LoB MS 3219/4/29/32.
} 
James Watt jr and Tom Wedgwood in actively seeking financial support for the MPI. In the end around 200 donors subscribed just over $£ 2000$. Just under a third of this money came from nineteen donations of more than $f 20$. Most of these high-end donations came from members of the Devonshire circle suggesting that concentrating on Beddoes connections with the Lunar Society in terms of financial support, at least, might be a bit misleading. ${ }^{82}$ Additionally, Wedgwood gifted $£ 500$ and Beddoes's deceased patient William Lambton (1764-1797) bequeathed $£ 300$. The combined Watt family contributed nineteen guineas, but this was not paid until November 1799; 83 Wedgwood's gift remained outstanding in March $1800 .^{84}$

As with so much else in late eighteenth-century England, aristocratic support and influence remained paramount. ${ }^{85}$ The reason why the general public appeal failed to raise the required amount, thus forcing Beddoes to rely heavily on his wealthy and aristocratic supporters, was due to his radical political views, which told against him. For example, despite her best efforts Devonshire (who disliked Beddoes's politics ${ }^{86}$ ) could not obtain the support of the President of the Royal Society of London, Joseph Banks (1743-1820). He regarded Beddoes's opposition 'to the present arrangement of the order of Society in this Country' as disqualifying him from support. However, he continued that her intervention had made him withdraw this view. Her lobbying had put Banks in a difficult position, since, as a gentleman, he clearly could not contradict her support for Beddoes on political grounds. Instead he concluded he could not endorse the project because he believed such medical experiments would do more harm than any conceivable good. ${ }^{87}$ Devonshire challenged this response but Banks remained unmoved. ${ }^{88}$ Watt sr then immediately threw his weight behind obtaining Banks's support drawing from him the request not to be lobbied any further having

\footnotetext{
82 Trevor H. Levere, 'Dr Thomas Beddoes (1760-1808) and the Lunar Society of Birmingham: Collaborations in Science and Medicine', British Journal for Eighteenth-Century Studies, 2007, 30: 209-26.

83 Thomas Beddoes to James Watt sr, 13 February 1799, LoB MS 3219/4/41/3. A note from mid-November 1799 listed their payment, LoB MS 3219/4/41/6 which was acknowledged in Thomas Beddoes to Gregory Watt, 21 November 1799, LoB MS 3219/6/2/B/74.

${ }^{84}$ Thomas Beddoes to Josiah Wedgwood, 20 March 1800, WM MS E1-569.

${ }^{85}$ Frank A.J.L. James, 'The Subversive Humphry Davy: Aristocracy and Establishing Chemical Research Laboratories in Late Eighteenth- and Early Nineteenth-Century England' in Lissa Roberts and Simon Werrett, eds., Compound Histories: Materials, Governance and Production, 1760-1840 (Leiden: Brill, 2007), pp.269-88.

${ }^{86}$ Duchess of Devonshire to Earl Spencer, 30 May 1796, British Library MS add 75923 (no foliation).

87 Joseph Banks to Duchess of Devonshire, 30 November 1794, Natural History Museum, Dawson Turner Collection, 9, f.125.

88 Duchess of Devonshire to Joseph Banks, 1 December 1794 and Joseph Banks to Duchess of Devonshire, 2 December 1794 in Neil Chambers, ed., The Scientific Correspondence of Joseph Banks (6 volumes, London: Pickering, 2007), 4: 1290 and 1292.
} 
'formally declined' to support Beddoes. ${ }^{89}$ This refusal angered Watt jr, who, much to his father's concern was at this time a Jacobin, having been in Paris at the start of what became the Terror: ${ }^{90}$

The fact is I suppose he [Banks] has seen Beddoes's cloven Jacobin foot and it is the order of the day to suppress all Jacobin innovations such as this is called. It is said to be the same spirit operating in a different way. Even the purity of my father's principles cannot absolve him from the contagion of the connection. I apprehend the secret committee of the Royal Society [of London] regard him [Watt sr] too as a lost sheep. ${ }^{91}$

Devonshire fared no better with her distant cousin-in-law Henry Cavendish, who, with Priestley, had done so much to promote pneumatic science. Beddoes was hopeful that Cavendish would support the project, ${ }^{92}$ but not being personally acquainted with him, Devonshire was deployed to gain his support. ${ }^{93}$ No evidence relating to Cavendish's reaction has been found; he did not subscribe and Watt jr thought he was the only man 'of real Chemical knowledge' who did not support the MPI. ${ }^{94}$ Even Beddoes's strongest supporters became frustrated with him. During 1795 Watt sr wrote bluntly to Beddoes twice. In March:

Doctors in London in general condemn the practice [of pneumatic medicine] in toto \& some other people are sure it must be bad $1^{\text {st }}$ because you believe in Lavoisiers theory, $2^{\mathrm{d}}$ because you have the character of a Jacobin $3^{\text {dly }}$ because they have found out from some expressions in your tracts on air that you are a Materialist ${ }^{95}$

And in November told him that his political activities 'will do more hurt to Pneumatics than you can possibly do good to the nation - amend your ways. ${ }^{96}$

\footnotetext{
89 James Watt sr to Joseph Banks, 7 December 1794 and Joseph Banks to James Watt sr, 10 December 1794, Banks, Scientific Correspondence, 4: 1295 and 1296. See also Hills, James Watt, p.158.

90 Peter M. Jones, 'Living the Enlightenment and the French Revolution: James Watt, Matthew Boulton and their sons', Historical Journal, 1999, 42: 157-82.

91 James Watt jr to John Ferriar, 19 December 1794, LoB MS 3219/6/7, pp.20-21. See also James Watt jr to Thomas Beddoes, 20 December 1794, LoB MS 3219/6/7, pp.21-2.

92 Thomas Beddoes to Thomas Wedgwood, 7 November 1794, WM MS MC 35.

93 Thomas Beddoes to James Watt jr, 9 November 1794, LoB MS 3219/6/2/B/57 noted Beddoes had requested her to contact Cavendish.

94 James Watt jr to John Ferriar, 19 December 1794, LoB MS 3219/6/7, pp.20-21.

95 James Watt sr to Thomas Beddoes, 2 March 1795, LoB MS 3219/4/124/377.

96 James Watt sr to Thomas Beddoes, 28 November 1795, LoB MS 3219/4/124/414.
} 
Nevertheless, fundraising continued and during 1797 despite not having obtained the sum originally thought necessary, Beddoes and some subscribers became convinced that sufficient funds had been raised to ensure the practicality of establishing the MPI. Discussions began as to its location (some were unconvinced Bristol was the most appropriate ${ }^{97}$ ) and to search for a suitable Superintendent. So far as the latter was concerned, Beddoes noted in October, despite 'many applications', he had been 'disappointed' at not yet having found one. ${ }^{98}$

\section{Davy at the Medical Pneumatic Institution}

Thus, Davy's appearance, in the form of his experimental descriptions and proposing theories agreeing with Beddoes's current views, as a possible and, despite his youth, appropriate Superintendent, must have seemed too good an opportunity to let slip. Beddoes was sufficiently impressed with Davy's paper together with Giddy's 'high opinion of his talents' to consider Davy, whom he had not yet met personally, for the position. He wrote to Watt sr in mid-July, as one of the key supporters of and significant subscriber to the MPI, that he should 'apply to Gregory' for further information about Davy. ${ }^{99}$ During his visit to Bristol on the way back from Cornwall in the second half of June, Gregory had clearly praised Davy to Beddoes.

By early July Beddoes had started negotiations for Davy's appointment, indicating to Giddy early that month a willingness to employ Davy, but could not yet specify what his salary might be. ${ }^{100}$ After receiving a letter from Davy asking to receive 'genteel maintenance', Beddoes, two weeks later, wrote again to Giddy asking him to find out what Davy meant by this ${ }^{101}$ - unfortunately we don't have Giddy's reply. Nor do we know anything about the negotiations that led Borlase to release Davy from the remainder of his apprenticeship, since without this legal requirement Davy would have been unable to move to Clifton. The problem was that Tonkin, who had, after all, paid Davy's premium, opposed his moving to Bristol. ${ }^{102}$ I would give a good deal to know the content of

\footnotetext{
${ }^{97}$ Thomas Beddoes to James Watt sr, 26 May 1797, LoB MS 3219/4/29/13.

${ }^{98}$ Thomas Beddoes to Thomas Girdlestone, 25 July 1797, private possession; Thomas Beddoes to James Watt sr, 24 October 1797, LoB MS 3219/4/29/23.

${ }_{99}$ Both quotations from Thomas Beddoes to James Watt sr, 15 July 1798, LoB MS 3219/4/29/32.

${ }^{100}$ Thomas Beddoes to Davies Giddy, 4 July 1798, Paris, Life of Sir Humphry Davy, 1: 53.

${ }^{101}$ Thomas Beddoes to Davies Giddy, 18 July 1798, Paris, Life of Sir Humphry Davy, 1: 53-4. A few months after arriving in Bristol Davy told his mother that he expected to make $f 200$ annually. Humphry Davy to Grace Davy, 19 January 1800, RI MS HD/26/A/2.

102 Paris, Life of Sir Humphry Davy, 1: 55.
} 
the conversation when Giddy dined with Tonkin at the start of September. ${ }^{103}$ Davy hoped he would be able to leave Penzance during the first half of that month, ${ }^{104}$ but it was not until 1 October 1798 when Borlase amended Davy's apprenticeship releasing him from his remaining time of sixteen and a half months. ${ }^{105}$ The following day he departed Penzance, ${ }^{106}$ the first time he had left Cornwall. At Okehampton, two days later, though whether by design or chance is not clear, he met Giddy returning from a visit to Tavistock. ${ }^{107}$

At Clifton, Davy found Beddoes had just moved into a large house in Rodney Place ('The houses in it are the best at Clifton \& I have bought the best' ${ }^{108}$ ). Davy told his mother that it was 'situated on the top of a hill commanding a view of Bristol \& its neighbourhood', but 'above all,' it possessed 'an excellent laboratory.' ${ }^{109}$ Sharing this house were Beddoes's wife, Anna Beddoes (17731824) and the two sons of his former patient William Lambton. They had been entrusted to Beddoes for their education before entering Eton and Davy had some responsibility in helping with this. One, John Lambton, later Earl of Durham (1792-1840), retained fond memories of Davy and played a significant role during the late 1810s in helping Davy establish his claim in the north east to the invention of the miner's safety lamp. ${ }^{110}$ Anna Beddoes, one of the many daughters of the Irish landowner and educational writer, Richard Edgeworth (1744-1817), was only five years older than Davy; she showed him around Clifton and they quickly became 'very great Friends'. ${ }^{111}$

Davy amply fulfilled the expectations placed on him and Beddoes reacted to him enthusiastically as did everyone else who met him at this time. Beddoes's patient the poet Robert Southey (1774-1843) wrote 'We have an extraordinary young man lately settled here,' while the lawyer James Losh (1763-1833) described Davy as 'a very extraordinary young man of twenty, profoundly acquainted with natural philosophy, and well read in most kinds of learning \& modest \&

\footnotetext{
${ }^{103}$ Giddy, Diary, 1 September 1798, CRO DG/16.

${ }^{104}$ Humphry Davy to Thomas Beddoes, c.10 September 1798, draft in RI MS HD/13/E, p.40 where he wrote that he would leave in a week and be in Bristol around the 25th.

105 Davy's apprentice indenture, RI MS HD/5/3 and RIC MS DVY/1.

${ }^{106}$ Davy, Memoirs of the Life of Sir Humphry Davy, 1: 59; Paris, Life of Sir Humphry Davy, 1: 55.

107 Giddy, Diary, 4 October 1798, CRO DG/16.

108 Thomas Beddoes to James Watt jr, October 1798, LoB MS 3219/6/2/B/72.

109 Humphry Davy to Grace Davy, 11 October 1798, RI MS HD/26/A/1.

${ }^{110}$ Frank A.J.L. James, 'How Big is a Hole?: The Problems of the Practical Application of Science in the Invention of the Miners' Safety Lamp by Humphry Davy and George Stephenson in Late Regency England', Transactions of the Newcomen Society, 2005, 75: 175-227.

${ }^{111}$ Humphry Davy to Grace Davy, 11 October 1798, RI MS HD/26/A/1.
} 
unaffected in his manners. ${ }^{112}$ To James Watt jr, Beddoes wrote 'I do not recollect to have conversed with a person of so great talents for experimental investigations, ${ }^{113}$ and to the significant MPI subscriber and MP Samuel Whitbread (1764-1815), that he had found 'a young man qualified beyond my most sanguine hopes to act as Superintendent. I propose that it $\mathrm{sh}^{\mathrm{d}}$ be under his management \& my own occasional inspection. I think to set it on foot immediately. ${ }^{.114}$ Publicly in The Monthly Magazine, Beddoes described Davy as 'A young man, endowed with talents for experimental researches at least equal to any person I have ever known. ${ }^{115}$

Beddoes entrusted Davy with the task of spending the money he had taken so long to raise and arranged for him to visit some of the MPI's major supporters. For instance, in early January 1799 Beddoes despatched Davy to the Midlands where he met Watt sr and his fellow industrialist James Keir (1735-1820). There he also met Gregory again and they spent their time going over his mineralogical cabinet. ${ }^{116}$ Davy agreed to send Gregory some mineral specimens, but these had not arrived by April when Gregory sent him some of the minerals he had seen on his visit. ${ }^{117}$ In the meantime towards the end of February the paper Davy had written while still in Cornwall had been published as two papers. ${ }^{118}$ Beddoes sent the Watts a copy; Watt sr, on the whole, was pleased with Davy's efforts, commenting that while 'it [is] highly ingenious \& in some part[s] exceedingly probable some part[s] I must doubt of'. In particular, as befitted the inventor of the separate condenser, he was concerned that if heat was not matter, could it still pass through a vacuum. Presciently he thought that in the future Davy 'will himself write against part of it', concluding 'Please to remember

\footnotetext{
${ }^{112}$ Robert Southey to William Taylor, 24 February 1799. James Losh, Diary, 20 November 1798, Carlisle Central Library MS.

${ }^{113}$ Thomas Beddoes to James Watt jr, October 1798, LoB MS 3219/6/2/B/72.

${ }^{114}$ Thomas Beddoes to Samuel Whitbread, 17 October 1798, Bedfordshire and Luton Archive Service MS W/1/4620.

${ }^{115}$ Monthly Magazine, 1798, 6: 238.

${ }^{116}$ Gregory Watt to Humphry Davy, 28 January 1799, RI MS HD/26/G/2.

117 Gregory Watt to Humphry Davy, 13 April 1799, RI MS HD/26/G/4.

${ }^{118}$ Humphry Davy, 'An Essay on Heat, Light, and the Combinations of Light' and 'An Essay On the Generation of Phosoxygen Or Oxygen Gas; And on the Causes of the Colors of Organic Beings,' in Beddoes, ed., Contributions to physical and medical knowledge, pp.5-147 and 149-98 with an addenda, pp.199-205. For date of publication see Davies Giddy to Thomasina Dennis, 28 February 1799, CRO DG/87/1/25.
} 
me to Mr Davy, also I hope [he] will excuse my criticisms' ${ }^{119}$ Similarly writing two days later, Gregory told Davy that he did not agree with all of the essay. ${ }^{120}$

During this period, both before and after his visit to the Midlands, Davy began the negotiations which resulted in acquiring a house for the MPI in Dowry Square. ${ }^{121}$ In March 1799 The Bristol Gazette carried an advert announcing the opening of the 'New Medical Institution' which would be attended, presumably daily, by Beddoes and Davy between 11am and $1 \mathrm{pm} .{ }^{122}$ Shortly afterwards, Davy drafted a 'Prospectus' for the MPI (though it is not clear if this was ever printed) writing that 'upwards of forty are become outpatients [at the MPI] within this fortnight \& we could immediately fill the house with in patients. ${ }^{\prime 23}$ The following month the number of out-patients had increased to eighty ${ }^{124}$ and by November five lady in-patients were being subjected to Beddoes's novel treatment of inhaling the breath of an Alderney cow. ${ }^{125}$

Following the MPI's opening, Davy began experimentation on dephlogisticated nitrous air as Priestley, its discoverer, had named it, or nitrous phosoxyd as Davy initially termed it before finally calling it, following Lavoisierian nomenclature, nitrous oxide. He discovered its pleasurable physiological action and self-experimented by frequently inhaling large quantities of the gas - on one occasion sixteen quarts (just over eighteen litres). ${ }^{126}$ In early September Watt sr and his wife had the opportunity to witness Davy's experiments when they visited Clifton for a few days as part of a tour of Wales and south west England looking for a suitable country estate. At the MPI Davy showed them the administration of gas to a couple of patients suffering from palsy. ${ }^{127} \mathrm{He}$ discussed with Watt sr the possibility of constructing a breathing chamber for the gases, who eventually suggested

\footnotetext{
119 James Watt sr to Thomas Beddoes, 11 April 1799, LoB MS 3219/4/118/173. Thomas Hope told John Davy that Davy, not long after publication, came to regret publishing the essays; Davy, Memoirs of the Life of Sir Humphry Davy, 1: 80.

${ }^{120}$ Gregory Watt to Humphry Davy, 13 April 1799, RI MS HD/26/G/4.

${ }^{121}$ Humphry Davy to Grace Davy, 11 October 1798, RI MS HD/26/A/1.

122 The Bristol Gazette, 21 March 1799, 3c.

${ }^{123}$ Humphry Davy, 'Prospectus of the design of the Institution,' [late March / early April 1799], RI MS HD/20/B, pp.11-16, quotation on p.14.

${ }^{124}$ Humphry Davy to Davies Giddy, 18? April 1799, Paris, Life of Sir Humphry Davy, 1: 79-82. Paris dated this letter 10 April 1799, but such a date contradicts other evidence. Davy's numbers can, on occasion, be confused.

125 Thomas Frankland to James Smith, 18 November 1799, Linnean Society MS JES/COR/15/6.

${ }^{126}$ Humphry Davy to Davies Giddy, 18? April 1799, Paris, Life of Sir Humphry Davy, 1: 79-82.

${ }^{127}$ Anne Watt to Gregory Watt, 6 September 1799, LoB MS 3219/7/1/52.
} 
something the size of a sedan chair, ${ }^{128}$ which Davy later described using. ${ }^{129}$ As did so many of Davy's acquaintances, such as the poets Southey and Samuel Taylor Coleridge (1772-1834), ${ }^{130}$ both Watt sr and Anne Watt inhaled nitrous oxide, though she nearly became hysterical. ${ }^{131}$ Following the return of his parents to Birmingham, Gregory and James Watt sr sought to make the gas but were unable to replicate its physiological effects - an issue explored by Jan Golinski. ${ }^{132}$ Gregory had to ask Davy 'by what process you generate sublime sensations and be the ladder by which we may ascend to the Heaven of Heavens'. ${ }^{133}$ He later achieved his desire, but the effect was not as great as on other people. ${ }^{134}$

Davy's sustained exposure to the gas damaged his health and so spent most of November 1799 in Cornwall, where he suffered withdrawal symptoms. After a gap of thirty-three days without the gas, he inhaled nine quarts on his return. ${ }^{135} \mathrm{He}$ described the results of his own experimentation and the accounts of many of Beddoes's Bristol circle whom he persuaded to inhale in his first book, Researches, Chemical and Philosophical; Chiefly Concerning Nitrous Oxide, or Dephlogisticated Nitrous Air, and its Respiration. Published in mid-1800, it cost half a guinea and ran to nearly six hundred pages. He divided the text roughly equally between providing a detailed chemical analysis of the gas and describing its physiological properties. Only towards the end, and then very briefly, did Davy reference any possible therapeutic use, though Beddoes thought there might be. ${ }^{136}$ In this research Davy had pursued his own agenda rather than the MPI's. ${ }^{137}$

\footnotetext{
128 James Watt sr and Gregory Watt to Humphry Davy, 13 November 1799, RI MS HD/26/G/3.

${ }^{129}$ Davy, Researches, p.485.

${ }^{130}$ For example, Robert Southey to Grosvenor Bedford, 5 June 1799 and Coleridge, [May or June 1800] in Davy Researches, pp.516-18.

131 James Watt sr to Joseph Black, 9 November 1799, Black, Correspondence 2: letter 826. Gregory Watt to James Watt sr, 9 September 1799, LoB MS 3219/7/49/22. For Watt sr, see also Thomas Beddoes, Notice of Some Observations made at the Medical Pneumatic Institution (London: Longman, 1799), p.20 while Anne Watt is probably the person referred to as "Mrs. W" in ibid., 18.

132 Jan Golinski, Science as Public Culture: Chemistry and Enlightenment in Britain, 1760-1820 (Cambridge: Cambridge University Press, 1992), p.170

133 James Watt sr and Gregory Watt to Humphry Davy, 13 November 1799, RI MS HD/26/G/3.

${ }^{134}$ Davy, Researches, p.536. See also Gregory Watt to James Watt sr, 19 October 1800, LoB MS 3219/7/50/7.

135 Davy, Researches, p. 478.

136 Beddoes, Notice.

137 James, 'The Subversive Humphry Davy'.
} 


\section{Electrical Researches}

A similar pattern of Davy pursuing his own agenda occurred after the news reached him, just as he was completing Researches, of an invention made by the Italian natural philosopher Alessandro Volta (1745-1827). Volta called his invention a pile (of acidified alternate metal plates) which produced galvanic electricity. Davy referenced it briefly right at the end of his Researches ${ }^{138}$ and Beddoes arranged for one to be built at the MPI. ${ }^{139}$ There, very quickly, it began to be called a battery, the term Giddy, then staying with Beddoes at Clifton but seeing Davy frequently, ${ }^{140}$ used in his diary when he witnessed some of Davy's galvanic experiments on 7 August. ${ }^{141}$ Davy referred to it as a battery in the draft of his first paper on galvanism stemming from those August experiments, but did not use it in the text published in the September issue of $A$ Journal of Natural Philosophy, Chemistry and the Arts; ${ }^{142}$ Davy first used the term in print in $1801 .{ }^{143}$

For the remainder of 1800 Davy experimented on galvanism. He sent the Lambton boys out onto Clifton Down to collect the toads necessary for detecting the presence of electricity. Following their apparent extinction on the down, Beddoes then ordered three hundred frogs (from where is not noted, but possibly from his native Shropshire). They arrived, but when the dock workers opened the cask many of the frogs perished in the 'deadly waters of the Frome', although the rest were saved for experimentation. However, and rather sinisterly, a story circulated and was still current nearly forty years later, that Beddoes had ordered 10,000 frogs to feed 'French jacobins concealed in ... [his] cellar'. Had it not been for the actions of a 'benevolent physician', the story went, Beddoes's house and perhaps Bristol itself might have been burnt. ${ }^{144}$ This surely references the Priestley riots in Birmingham nine years before and perhaps suggests the existence of a

\footnotetext{
138 Davy, Researches, p.568.

${ }^{139}$ A Journal of Natural Philosophy, Chemistry and the Arts, 1800, 4: 275.

140 Humphry Davy to Grace Davy, 27 September 1800, SM MS 333/2.

141 Davies Giddy, Diary, 7 August 1800, CRO MS DG/16.

${ }^{142}$ RI MS HD/20/C, p.10; Humphry Davy, 'An Account of some Experiments made with the Galvanic Apparatus of Signor Volta', A Journal of Natural Philosophy, Chemistry and the Arts, 1800, 4: 275-81.

143 Humphry Davy, 'An Account of Some Galvanic Combinations, Formed by the Arrangement of Single Metallic Plates and Fluids, Analogous to the New Galvanic Apparatus of Mr. Volta', Philosophical Transactions, 1801, 91: 397-402, p.400. For the introduction, earlier in the eighteenth century, of the term 'battery' to describe rows of Leyden jars see Simon Werrett, Fireworks: Pyrotechnic Arts and Sciences in European History (Chicago: Chicago University Press, 2010), pp.185-6.

${ }^{144}$ This story was recounted by the geologist William Buckland at the 1836 meeting of the British Association held in Bristol. John King, a colleague of Beddoes's in his later years and probably the benevolent physician, immediately published a correction in The Bristol Mercury, 8 October 1836, 4c.
} 
government agent provocateur in Bristol, where certainly Beddoes was unpopular with the governing classes as his failed attempts to secure planning permission for a scientific lecture theatre testify. ${ }^{145}$ Beddoes never did take Watt sr's advice about his political activities.

Beginning in August 1800, Davy recorded his electrical research in two notebooks, ${ }^{146}$ and in a series of papers published monthly (apart from January) in A Journal of Natural Philosophy, Chemistry and the Arts from September 1800 through to February $1801 .{ }^{147}$ In these papers Davy announced, amongst other discoveries, that electricity would pass through organic tissue, that charcoal could be used as an electric pole and came to the overall conclusion, contra Volta, that ‘Galvanism ... [was] a process purely chemical. ${ }^{148}$ Such conclusions confirmed Davy's view in his notebook entry, written probably during the middle part of 1799 , that 'Chemistry must no longer [be] considered as a science important because it is connected with our artificial wants; but because it promises to unfold to us the laws of our own existence. ${ }^{149}$ Right from the start, Davy believed the study of galvanism would 'acquaint us with some of the laws of life!,'150 a view stemming ultimately from the origin of galvanism in animal electricity. Once again Davy displayed little concern as to whether his work had any therapeutic value or relevance to the MPI's programme. It excited, however, the interest of Watt sr who suggested various experiments to Davy. ${ }^{151}$

Beddoes, also believing they were close to reaching an understanding of living systems, sought to take advantage of Davy's straying, by arguing that to exploit his work (and thus continue pursuing the MPI's stated aims) would require 'the most extensive application of chemistry to physiology. ${ }^{152}$ To achieve this he would need to appoint an expert anatomist as well as an instrument maker and establish a manufactory on the scale of Boulton and Watt's recently completed foundry for constructing steam engines at Soho, then one of the largest industrial

\footnotetext{
145 James, 'the first example', pp.32-3.

${ }^{146} \mathrm{RI} \mathrm{MS} \mathrm{HD/20/C}$ and /22/B.

147 Detailed in June Fullmer, Sir Humphry Davy's Published Work (Cambridge, MA: Harvard University Press, 1969).

148 Humphry Davy to Davies Giddy, 20 October 1800, private possession, but also Paris, Life of Sir Humphry Davy, 1: 108-11.

${ }^{149} \mathrm{RI} M S \mathrm{HD} / 20 / \mathrm{A}, \mathrm{p} .266$.

150 Humphry Davy to Davies Giddy, 3 July 1800, Paris, Life of Sir Humphry Davy, 1: 85-8.

151 James Watt sr to Humphry Davy, 6 December 1800, LoB MS 3219/4/118/278; Humphry Davy to James Watt sr, 7-8 January 1801, LOB MS 3219/4/43/19; James Watt sr to Humphry Davy, 11 January 1801, LoB MS $3219 / 4 / 118 / 293$.

152 Beddoes, Notice, p.34.
} 
facilities in the world. ${ }^{153}$ Beddoes pointed out, somewhat unnecessarily, that additional funding would be required ${ }^{154}$ - one does have to wonder how far Beddoes, or indeed anyone else, believed his own unrealistic fantasy and rhetoric. He essentially used the success of Davy's discovery to make a case for significant extra financial support for the MPI. In this he thought of Davy as a valuable resource, writing that he considered the effect of his presence 'as more than virtually doubling the fund. ${ }^{155}$

\section{Davy's Career and Gregory Watt's Death}

What Davy did in Bristol was simply a continuation of the start of his chemical career. Using locally available resources Davy, under the influence of Giddy, Tom Wedgwood and Gregory Watt in Penzance, had developed his ability and enthusiasm for chemical theorising and practical experimentation. Such skills were just what Beddoes needed, signified by his immediately praising Davy's experimental prowess. With his already existing experience Davy took full advantage of the resources Beddoes provided in Bristol. Davy's work was thus crucial to making the MPI a success in areas other than the intended one of determining the therapeutic value of gases. Left largely to his own devices, Davy made a significant medico-chemical discovery, published his first book and commenced electrical experimentation which he clearly believed had further potential, especially in understanding life.

But Davy also realised he had major problems with his career due to 'the political odium attached to its [the MPI's] founder.' ${ }^{156}$ In August 1800 the pro-government Anti-Jacobin Review had published a coruscating attack on Beddoes, also referencing, unfavourably, Davy's work on nitrous oxide. ${ }^{157}$ And the circulation of the frog story would have only served to heighten Davy's concerns. Furthermore, owing to the non-survival of papers detailing the MPI's day to day operations, we have no knowledge of its expenditure pattern, only that Davy was paid $£ 200$ annually. ${ }^{158}$ With only finite resources, especially if Tom Wedgwood's donation was still outstanding, it would have been apparent to him that the MPI's duration would be limited - as Beddoes had originally intended in

\footnotetext{
153 Jones, Industrial Enlightenment, p.55.

154 Beddoes, Notice, pp.35-6.

155 Beddoes, Notice, p.6.

156 Humphry Davy to John Tonkin, 12 January 1801, Davy, Memoirs of the Life of Sir Humphry Davy, 1: 107-9.

157 The Anti-Jacobin Review and Magazine, 1800, 6: 424-8.

158 Humphry Davy to Grace Davy, 19 January 1799, RI MS HD/26/A/2.
} 
1794 when he started raising funds. Davy's continuing connection with a known political radical would be an increasing liability in finding alternative employment, so perhaps it is not too surprising about two years after his arrival in Bristol, he began considering his future prospects. In a couple of letters written in September and November 1800, he hinted to his mother that he was looking to move from the MPI, ${ }^{159}$ whilst in the latter month writing from Lisbon, Southey opined: 'Davy will not always remain at the Pneumatic Institution. ${ }^{.160}$ Though it is not clear what options might then have been open to him, by early January he had begun negotiating to move to the newly founded Royal Institution in London. ${ }^{161}$ On 11 March 1801 Davy took up the positions of 'Assistant Lecturer in Chemistry, Director of the Chemical Laboratory, and Assistant Editor of the Journals of the Institution' at an annual salary of 100 guineas plus accommodation. ${ }^{162}$ This seems to represent a diminution in income, suggesting some keenness on Davy's part to leave Bristol. Gregory Watt was one of the first people he told, exaggerating his initial role by describing it as professor of chemistry. ${ }^{163}$

All through his and Davy's friendship, Gregory's health had not been good and towards the end of 1801, it began to deteriorate. At the beginning of August, he set out for the German speaking lands, but the signing at the end of September of the Preliminaries of what became the Peace of Amiens, meant he could now visit France. ${ }^{164}$ While in Paris he met Rumford who on his return to London gave Davy a fairly optimistic account of Gregory's health which he passed onto his father. ${ }^{165}$ Gregory left Paris in the mid-February 1802 and headed for Italy, where he undertook some important geological work, ${ }^{166}$ including ascending Vesuvius, returning to England in mid-October. Davy noted his arrival in a letter to Giddy, but reported 'his health is at present bad. I trust, however, that English roast-beef and English customs will speedily restore it. ${ }^{167}$ If Gregory took

\footnotetext{
${ }^{159}$ Humphry Davy to Grace Davy, 27 September 1800, SM MS 333/2 and 19 November 1800, Davy, Memoirs of the Life of Sir Humphry Davy, 1: 105-7.

${ }^{160}$ Robert Southey to William Taylor, 26 November 1800.

161 Humphry Davy to Grace Davy, 31 January 1801, SM MS 333/4.

162 RI MS MM, 16 February 1801, 2: 134.

${ }^{163}$ Gregory Watt to James Watt sr, 7 March 1801, LoB MS 3219/7/50/11.

${ }^{164}$ Hugh S. Torrens, 'The geological work of Gregory Watt, his travels with William Maclure in Italy (18011802), and Watt's "proto-geological” map of Italy (1804)' in G.B. Vai, W. Glen and E. Caldwell, eds., The Origins of Geology in Italy (Boulder: Geological Society of America, 2006), pp.179-97, p.182 seems not to have understood the significance of the Preliminaries.

165 Humphry Davy to James Watt sr, 29 December 1801, LoB MS 3219/4/43/20.

166 Torrens, 'The geological work of Gregory Watt'.

167 Humphry Davy to Davies Giddy, 26 October 1802, Paris, Life of Sir Humphry Davy, 1: 156-9.
} 
Davy's dietary advice, it did not do him any good. At the end of 1803 Watt jr told Tom Wedgwood, 'Gregory has been very far from well ever since his return from the Continent and for the last 4 or 5 months has been worse. ${ }^{168}$ Despite this Gregory kept on working, reviewing for the new Whig Edinburgh Review, undertaking an extensive series of chemical experiments where he sought to replicate the geological processes that had formed basalt (having access to Boulton and Watt's furnaces was a great advantage here) and in preparing a long paper for the Philosophical Transactions on this research. He may have just lived long enough to see a printed copy of his paper read to the Royal Society of London on 10 May $1804 .{ }^{169}$ He died on 16 October 1804 at Exeter just a couple of months before his $27^{\text {th }}$ birthday, and was buried in the south transept of the cathedral in a grave marked simply 'G.W. | Octr. 1804 | A[et] 27'. His mother had noted the month before that he kept studying. ${ }^{170}$

Gregory's death prompted Davy to write a meditation on the nature of death in a letter to William Clayfield (1772-1837), another member of Beddoes's circle in Bristol:

Poor Watt! - He ought not to have died. I could not persuade myself that he would die; and until the very moment when I was assured of his fate, I would not believe he was in any danger ${ }^{171}$

Gregory had been Davy's primary link with the Watt family and after his death it is noticeable he had little to do with other family members. However, as President of the Royal Society of London in the 1820s Davy promoted Watt sr's reputation as David Miller and Christine MacLeod have discussed. ${ }^{172}$

The only direct references in the Watt papers after Gregory Watt's death occur in late 1804 when Watt jr gave Davy a copy of a statuette of Venus made by Watt sr's machine ${ }^{173}$ and in 1807 when Beddoes discussed Davy's electro-chemical researches in a couple of letters to Watt sr. ${ }^{174}$ Davy

\footnotetext{
168 James Watt jr to Tom Wedgwood, 22 December 1803, WM MS E4-3324.

${ }^{169}$ Gregory Watt, 'Observations on Basalt, and on the Transition from the vitreous to the stony Texture, which occurs in the gradual Refrigeration of melted Basalt with some geological Remarks', Philosophical Transactions, 1804, 94: 279-314.

${ }^{170}$ Anne Watt to James Watt jr, 4 September 1804, LoB MS 3219/6/1/243.

${ }^{171}$ Humphry Davy to William Clayfield, second half October 1804, Paris, Life of Sir Humphry Davy, 1: 198-200.

172 David Philip Miller, Discovering Water: James Watt, Henry Cavendish and the Nineteenth-Century 'Water Controversy' (Aldershot: Ashgate, 2004), pp.102-3; Christine MacLeod, Heroes of Invention: Technology, Liberalism and British Identity, 1750-1914 (Cambridge: Cambridge University Press, 2007), p.101.

${ }^{173}$ Humphry Davy to James Watt jr, 16 December 1804, LoB MS 3219/6/2/D/7.

${ }^{174}$ Thomas Beddoes to James Watt sr, 20 June 1807 and 22 November 1807, LoB MS 3219/4/48/10 and 11 respectively.
} 
promised to look for letters relating to Gregory that would be of interest to the family, ${ }^{175}$ though their current location Royal Institution's archives suggests he didn't find them. Despite the paucity of references to Davy in the written record, there may have been one long term tribute that Davy paid to Gregory. After Gregory's death and for the rest of his own life, Davy devoted an enormous amount of effort to mineralogy and chemical geology, especially understanding basalts. His visits to Staffa, to Giant's Causeway, his later explorations of volcanoes in France and Italy, including following Gregory's footsteps on Vesuvius, all provide evidence of this interest, though he only published on the subject just before his own death. ${ }^{176}$

\section{Conclusion}

What this story of the interactions and the relations of the Watt family, Beddoes, Giddy and Davy illustrates is the numerous contingencies, both global and local, that propelled Davy from provincial obscurity to metropolitan fame. For instance, had Davy's father not died with significant debt it is possible he would have gone to university and perhaps become an Anglican clergyman, as Shute Barrington, Bishop of Durham (1734-1826) later suggested he should; ${ }^{177}$ had Gregory Watt and Tom Wedgwood not wintered in Penzance during 1797/8, which they did because of the war against Revolutionary France, it is entirely possible Davy would have remained a small town apothecary writing poetry; had both of them not been so ill, Beddoes's influence on their lives and vice versa (in that there would have been no need for them to so strongly support the MPI) could, equally plausibly, have been minimal and so on. Notions of a self-conscious scientific career or of a scientific community during the late eighteenth and early nineteenth centuries are seriously anachronistic, making no sense at all; ; ${ }^{178}$ there was no path to follow or community to join - each individual's route was different and highly contingent. And the same applies to the construction of scientific institutions at the time, as the cases of the MPI and Royal Institution illustrate. ${ }^{179}$

When one gets down to very detailed tracking of events as I have done in this essay, through contemporary correspondence, dairies and notebooks, as well as printed sources, notions of

\footnotetext{
${ }^{175}$ Reported in William Henry to James Watt sr, 9 January 1805, LoB MS 3219/7/59/7a.

${ }^{176}$ Frank A.J.L. James, 'Negative Geology: Humphry Davy and the Forming of the Royal Institution's Mineralogical Collection, 1803-1806', Earth Sciences History, 2018, 37: 309-32.

177 Davy, Memoirs of the Life of Sir Humphry Davy, 1: 272.

178 Golinski, The Experimental Self, p.1. Note, however, he devoted only a couple of pages (pp.20-21) to Davy's life before his arrival in Bristol.

179 James, 'The Subversive Humphry Davy'.
} 
direction, progress, order, rationality etc melt away and one is left simply with contingency and agency, most of the latter relating to perceived self-interest. In describing and, in this case, explaining the role of the Watt family in Davy's rise, there is no need, pace Occam's razor, to invoke the existence at that time (or for that matter now) of some sort of meta-narrative about the relations of scientific knowledge and method with engineering and industrialisation. Indeed, drawing on his extensive knowledge of Cornish mining, Watt sr thought even mineralogy did not 'advance' business. ${ }^{180}$ Furthermore, meta-narratives of description or explanation, such as Enlightenment or Romanticism, do not appear to operate at this level but provide inappropriately easy a priori explanations. At best, what is represented by these terms are the collective products of the contingency and agency experienced and responded to by individuals. In Davy's case, they can and have obscured historical understanding of his skill in appreciating and grasping how to take advantage of the opportunities presented to him, which the Watt family, among others, provided.

180 James Watt sr to James Watt jr, 3 October 1790, LoB MS 3219/6/1/77. 